\title{
Propagating structures and some factors that affect the rooting performance of Shea (Vitellaria paradoxa Gaertn) stem cuttings
}

\author{
Yeboah, J, Lowor, S. T., Amoah, F. M. and Owusu-Ansah, F. \\ Cocoa Research Institute of Ghana P. O. Box 8, Tafo-Akim, Ghana
}

\begin{abstract}
The shea is an economic tree found in West and Central Africa with huge industrial and domestic uses for the butter. However, its rapid multiplication has been hampered by its slow growth and long gestation period. Factors that affect vegetative propagation are physiological, biochemical and environmental. A factorial experiment was carried out to study the type of structure(s) that can be used to enhance the rooting performance of shea stem cuttings. A significantly $(P<0.05)$ higher rooting was achieved for cuttings set in the propagating bin (63.3\%) and polythene propagator $(57.5 \%)$. Significant $(P<0.05)$ differences between infection rates on cuttings in the structures were observed with the polythene tunnel recording the highest (64.4\%). High rooting performance and low infection rate were recorded when the cuttings were irrigated once daily, producing more and longer roots. Significantly $(P<0.05)$ high number of rooted cuttings was observed for cuttings with retained petioles. This treatment also significantly reduced infection rate. Seradix 3 powder treated cuttings significantly recorded the highest number of rooted cuttings. Cuttings with retained petioles and irrigated once daily significantly recorded high levels of soluble, insoluble sugars and total free phenols.
\end{abstract}

Keywords: Petiole; Shea; Vegetative propagation; Polythene tunnel; Polythene propagator; propagating bin

\section{INTRODUCTION}

The shea tree belongs to the Sapotaceae family, growing wild in West and Central Africa. It is an important tree species acting as source of income for many populations of semi-arid West Africa. The fruit pulp contains large quantities of vitamin $\mathrm{C}$, proteins and minerals (Maranz et al., 2004; Pearson, 1976) and is widely consumed during the fruiting season which coincides with the a famine period. Butter obtained from the kernel is used traditionally as source of fat in many African kitchens and in local traditional medicines. Industrially, it finds application in chocolate, cosmetic and pharmceutical industries. In addition, the tree improves microclimate and soil fertility for associated staple crops in agroforestry parklands, with branches serving as firewood and sawn logs (Hall et al., 1996 and Bayala et al., 2002). Propagation and cultivation is however hampered by its slow growth and long gestation period.

Vegetative propagation technique is one way of multiplying and improving clones for cultivation and research. It is mostly practiced for horticultural crops for the production of good materials within a short period. The responses of different tree crops to this method vary considerably according to their genetic constitution (Nanda et al., 1968). Methods of vegetative propagation (grafting, budding, layering and cutting) can be used for the shea tree. With the exception of grafting and cutting, the others show little success. Opoku-Ameyaw et al. (1996) using airlayering achieved $33.3 \%$ and $22.2 \%$ success respectively with softwood and semi-hardwood at the Cocoa Research Institute of Ghana substation, Bole while grafting is showing success in a range of 20$85 \%$ in Burkina Faso and Mali (Haby et al., 2004). Cuttings unlike grafting on seedlings can be rapidly multiplied yearly through rooting for the establishment of plantations while grafting can only be done when the seedlings are between 2-5 years because of the slow growing nature of shea (Yeboah pers com). Irrigation also plays a very important role in the rooting of cuttings by promoting vegetative growth, maintaining humidity and preventing the cuttings from drying out (Zahner, 1968). Retaining of short petioles on cuttings as observed by Nawrocka-Grzeskowiak and Grzeskowiak (2003) protects them from infections, leaching during irrigation and rapid wound healing at the point of attachment between the petiole and the cutting. Propagation by stem cuttings of recalcitrant species requires high technical expertise to achieve an acceptable rooting percentage. Specialized facilities are required to produce rooted cuttings, thus making it difficult for commercial 
farmers to adopt on a large scale. Several workers (Murray and Bridge, 1956; Mackelvie, 1957; Nichols, 1958) have attempted to simplify the technique of rooting cuttings that could be of wider application by commercial farmers. Yeboah (2005) and OpokuAmeyaw et al. (2000) working on shea cutting propagation achieved an average rooting success $(60 \%)$ using the polythene propagator. Other structures which have not been tried in shea propagation are the polythene tunnel and propagating bin. These two structures can also provide similar micro climate for cuttings thus enhancing rooting success. This study was aimed at assessing the effect of structure type, petiole retention on cuttings, irrigation and hormone application on rooting performance of shea cuttings.

\section{MATERIALS AND METHODS}

Two (2) experiments were carried out at the Cocoa Research Institute substation at Bole in the Northern region of Ghana (Fig. 1) between 2003 and 2004. Bole is located at an altitudinal range of $100-600 \mathrm{~m}$ with one rainfall maxima which occurs between May and September giving a precipitation of range of 600 $1400 \mathrm{~mm}$ every year. High humidity figures are observed during the rainy period. Mean annual temperature ranges between $25-29^{\circ} \mathrm{C}$.

\section{Rooting of stem cuttings}

The structures used in the experiments were the polythene propagator, propagating bin and the polythene tunnel. The polythene propagator (Figure 2) measured $4 \mathrm{~m} \times 1.30 \mathrm{~m} \times 0.6 \mathrm{~m}$ and had three sections (apartments). The propagating bin, similar to the polythene propagator, was made of concrete $(0.15 \mathrm{~m}$ thick with sections). The lid of the propagating bin consisted of a wooden frame covered with transparent polythene sheet (Figure 3).

The polythene tunnel is a rectangular wooden structure, which is higher than the polythene propagator and propagating bin, was also covered with transparent polythene sheet. Three (3) trenches (apartments) which measured $0.75 \mathrm{~m} \times 0.66 \mathrm{~m} \times 0.15$ $\mathrm{m}$ were dug in it to contain the medium for the experiment (Figure 4).

Stones formed the base material to $0.30 \mathrm{~m}$ thick followed by gravels $(0.20 \mathrm{~m}$ thick on top of the stones) then the main medium, rice husk $(0.20 \mathrm{~m}$ thick on stop of the gravels). Rice husks recommended (Ofori-Gyamfi, 1998) as a good medium was used in all the structures. Rice husk was sterilized by drenching in boiled water for 15 minutes.

Six leaves were retained on each cutting as recommended by Opoku-Ameyaw et al. (2000). Seradix ' 3 ' powder (active ingredientIndolebutyricacid - IBA) hormone at a concentration of 8000ppm was used. The cuttings were dipped in the hormone to $0.05 \mathrm{~m}$ from the base for five seconds before setting in the medium. The spacing between the cuttings was $14 \mathrm{~cm}$. Twenty (20) cuttings per treatment were used for each experiment. Three (3) cuttings/ treatment were randomly sampled from each structure to determine the soluble, insoluble sugars and total free phenols following the methods of Dubois et al. (1956) and Swain and Hillis (1959) respectively. Temperatures of the environment and the medium in the structures were daily recorded with a thermometer (inserted in the medium) during the rooting period.

Data collected on the trials were number of rooted cuttings; number of callused cuttings; number of dormant cuttings; number of roots per cutting; root length; degree of fungal infection.

Root length was measured with a meter rule. Data were collected on cuttings, which had rooted, those that were dormant and those that had callused during the rooting period (from the $30^{\text {th }}$ to $120^{\text {th }}$ day).

Experiment 1: Effect of structure type, petiole (leaf stalk) retention and hormone application on the rooting performance of rejuvenated stem cuttings from coppiced shea trees.

The experiment involved three factors, namely type of structure (propagating bin, polythene tunnel and the polythene propagator), retention of petiole (with/without petiole) and hormone (with/without). This was laid out in a randomized complete block design with three replicates. Monitoring was done once every three days to remove fallen and infected leaves and dead and infected cuttings. Cuttings in each structure were watered with 14 litres of water daily. Signs of rooting were assessed by counting the number of cuttings that had rooted, those that were dormant or had callused in the structures at 3-day interval from 30 to 120 days after setting. The parameters considered were the number of cuttings rooted, callused, and dormant, degree of infections, root length and number of roots developed per cutting. 
Experiment 2: Effect of structure type, irrigation and hormone application on the rooting performance of rejuvenated stem cuttings from coppiced shea trees.

A 3x3×2 factorial experiment was set up in June 2004 using three different structures (propagating bin, the polythene tunnel and the polythene propagator), three levels of irrigation (once, twice and thrice daily) and two levels of Seradix hormone (with/without) application on rejuvenated shoots of shea cuttings. The experiment was laid out in a randomized complete block with three replicates and 20 cuttings per treatment. Monitoring was done to remove all cuttings infected with fungi and dead leaves. Checking for signs of rooting was done at 3-day interval from 30 to 120 days after setting. Records were taken on the number of rooted, callused, dormant cuttings, number of roots developed and as well as the number of cuttings infected with fungi by daily counting while root length was measured with a meter rule.

Statistical analysis: The data was angular transformed prior to analysis to stabilize the variances and normalize the residuals. Analysis of variance was performed on the transformed data using Genstat (9.2). The least significant difference test (LSD) was employed to determine differences between means at a 5\% significance level.

\section{RESULTS AND DISCUSSION}

Experiment one: High temperatures $\left(23-40^{\circ} \mathrm{C}\right)$ were recorded in the rice husk medium of the polythene tunnel than in the two other structures during the experimental period. Temperatures recorded in the propagating bin were moderate (Tables 1 \& 2). The difference in temperatures between the propagating bin and polythene propagator was negligible.

Table 1: Mean monthly temperature and humidity of the environment from June to October, 2004

\begin{tabular}{|l|c|c|c|c|}
\hline Month & \multicolumn{2}{|c|}{ Temperature $\left({ }^{\circ} \mathrm{C}\right)$} & \multicolumn{2}{c|}{ Humidity (\%) } \\
\hline & Minimum & Maximum & Minimum & Maximum \\
\hline June & 24.2 & 30.5 & 67 & 87 \\
\hline July & 24.6 & 29.8 & 71 & 88 \\
\hline August & 25.0 & 31.2 & 71 & 89 \\
\hline September & 25.7 & 31.7 & 68 & 80 \\
\hline October & 21.5 & 32.0 & & \\
\hline
\end{tabular}

Table2: Mean monthly medium (rice husk) temperature $\left({ }^{\circ} \mathrm{C}\right)$ in the Polythene propagator, Propagating bin and Polythene tunnel structures

\begin{tabular}{|l|l|l|l|l|l|l|}
\hline & Polythene propagator & \multicolumn{4}{l|}{ Propagating bin } & \multicolumn{2}{l|}{ Polythene tunnel } \\
\hline Month & Min & Max & Min & Max & Min & Max \\
\hline June & 24.5 & 29.5 & 24.0 & 28.6 & 25.9 & 30.7 \\
\hline July & 24.8 & 30.0 & 24.1 & 29.8 & 25.5 & 31.9 \\
\hline August & 25.6 & 31.8 & 24.8 & 30.1 & 26.7 & 32.0 \\
\hline September & 25.6 & 31.0 & 24.4 & 29.5 & 27.0 & 31.9 \\
\hline October & 22.8 & 30.1 & 22.6 & 30.4 & 23.2 & 32.8 \\
\hline
\end{tabular}

The number of callused cuttings and number of roots developed per cutting were not significantly influenced by the type of structure used (Table 3). However, the propagating bin had significantly more $(p<0.05)$ rooted cuttings and longer roots than the polythene tunnel. There were no significant differences between the bin and the polythene propagator except for the root length. This may be explained by the temperatures recorded in the structures (Table 2). The temperature range recorded in the propagating bin was similar to what had been reported by Moore et al. (1975). They observed that, temperatures ranging between $22^{\circ} \mathrm{C}-24^{\circ} \mathrm{C}$ and $28^{\circ} \mathrm{C}$ - $30^{\circ} \mathrm{C}$ were suitable for carbohydrate metabolism, cell division and root initiation. Henselova et al. (2002) proposed that to achieve successful rooting for stem cuttings, the maximum temperature should not exceed $28^{\circ}$ C. Nawrocka-Grzeskowiak and Grzeskowiak (2003) working with Azalea shoot cuttings observed that a controlled temperature range of $20-25^{\circ} \mathrm{C}$ enhanced rooting performance. The poor rooting success in the polythene tunnel could be attributed to the high medium temperatures (Table 2). Suitable air temperature for rooting was observed 
and recorded in the propagating bin and polythene propagator (Preece, 1993). The polythene tunnel recorded temperatures beyond the optimum air temperature which might have contributed to the poor rooting performance.

The rooting percentage in the cuttings with retained petiole $(56.7 \%)$ was significantly higher than those without petiole (Table 3), indicating that petiole retention was effective in promoting rooting in cuttings. Nawrocka-Grzeskowiak and Grzeskowiak (2003) working with Azalea cuttings achieved good rooting when short petioles were retained. Cuttings without petioles were more susceptible to gradual leaching of the soluble plant substances (sugars and phenols) during the irrigation (Hartmann et al., 2002). Reduction of these nutrients through leaching slows down metabolic activities in the cuttings and results in callus formation instead of rooting.

Applying Seradix powder on the cuttings significantly $(p<0.05)$ influenced the rooting performance, increased number of developed roots and root length while the other parameters were not different (Table 3 ). The production of adventitious roots in plants is controlled by growth substances (Davis and Hassig, 1990) and a key role in this process is played by auxins. Lux et al. (2002) observed that the active role played by IBA in a mixture of IBA and NAA enhances rooting of Karwinskia species. Middleton et al. (1980) emphasized that carbohydrates form conjugates with the auxins (endogenous and exogenous) thus preventing the latter, auxins (which enhances metabolism of carbohydrate in leaves, upper stem and increased transport to the rooting zone) from being destroyed by indoleacetic acid oxidase (IAAoxidase). Growth and development of the root primordium as suggested by Gorter (1969) occurred due to the presence of boron $(B)$, while $B$ in the presence of auxins helped in inducing rooting from the primordial stage as observed by Middleton et al. (1978).

The structure $x$ petiole retention $x$ hormone interaction was not significant for the number of roots developed per cutting (Table 3). Significantly $(P<0.05)$ higher rooting was observed for cuttings, which were set in the propagating bin with retained petioles and dipped in Seradix powder while low rooting was recorded in the tunnel for cuttings set without petioles and Seradix powder. The tunnel recorded high medium temperature range of $23^{\circ} \mathrm{C}$ $27^{\circ} \mathrm{C}$ and $30^{\circ} \mathrm{C}-32^{\circ} \mathrm{C}$ which adversely affected rooting.

The cuttings with retained petioles in each of the structures had higher sugar and phenol levels than the cuttings without petioles (Table 4). Cuttings with retained petioles in the propagating bin significantly $(P<0.05)$ had higher levels of sugars and phenols but did not differ from the levels in cuttings with the same treatment in the polythene propagator. However, cuttings without petioles in the polythene tunnel had the lowest level of sugars and phenols.

Experiment two: Cuttings in different structures have significantly different rooting abilities (Table 5 ). No significant differences were observed for dormant cuttings and number of roots developed per cutting. However, the propagating bin recorded high rooting with the polythene tunnel giving low rooting performance. Long roots were recorded for cuttings set in the propagating bin. Hartmann et al. (2002) observed that structures that retain moderate temperatures enhance rooting performance and this was also observed by Ofori-Gyamfi (1998). The propagation bin gave high rooting due to its moderate temperatures.

Frequency of irrigation had significant effect on the number of rooted cuttings and number of roots developed per cutting. High number of rooted cuttings and roots developed per cutting were recorded from irrigating once daily than the other treatments. Balestrini and Vartanian (1983) reported that water in vegetative propagation is important as it helps in maintaining relative humidity and reducing the temperature for cell division and biochemical processes. However, excessive irrigation (twice and thrice daily) had a negative influence on rooting success (Table 5) (Erstad and Gislerod, 1994; Rein et al., 1991). 
Agric. Biol. J. N. Am., 2011, 2(2): 258-269

Table 3: Effect of propagating structure, petiole retention and hormone application and their interaction on the rooting performance of shea stem cuttings.

\begin{tabular}{|c|c|c|c|c|c|}
\hline \multirow{2}{*}{ Treatments } & \multicolumn{3}{|c|}{$\%$ of cuttings alive after 120 days } & \multirow{2}{*}{$\begin{array}{l}\text { No. of roots } \\
\text { per cuttings }\end{array}$} & \multirow{2}{*}{$\begin{array}{l}\text { Average root length } \\
\qquad(\mathrm{cm})\end{array}$} \\
\hline & Rooted & Callused & Dormant & & \\
\hline \multicolumn{6}{|l|}{ Structure } \\
\hline Pprop & $57.5(49.9)$ & $12.5(16.6)$ & $23.5(25.0)$ & 4.3 & 9.1 \\
\hline Pbin & $63.3(53.1)$ & $15.0(19.6)$ & $10.0(16.7)$ & 4.4 & 13.1 \\
\hline Ptunnel & $22.5(26.6)$ & $18.3(22.6)$ & $30.0(31.3)$ & 4.4 & 8.9 \\
\hline $\operatorname{LSD}(P=0.05)$ & $(7.8)$ & (ns) & $(9.5)$ & ns & 2.0 \\
\hline \multicolumn{6}{|l|}{ Petiole retention } \\
\hline Ret & $56.7(45.5)$ & $13.9(18.7)$ & $15.0(18.9)$ & 4.5 & 10.4 \\
\hline Nret & $38.9(37.2)$ & $16.7(20.5)$ & $28.0(29.4)$ & 4.0 & 8.3 \\
\hline $\operatorname{LSD}(P=0.05)$ & $(6.4)$ & (ns) & $(7.8)$ & ns & 1.6 \\
\hline \multicolumn{6}{|l|}{ Horm. Appli } \\
\hline Ctrl & $45.0(40.9)$ & $20.6(20.0)$ & $23.3(26.2)$ & 4.3 & 8.8 \\
\hline S3P & $50.6(46.5)$ & $10.6(14.2)$ & $20.0(21.5)$ & 4.3 & 9.9 \\
\hline $\operatorname{LSD}(P=0.05)$ & $(5.1)$ & (ns) & (ns) & ns & 1.0 \\
\hline \multicolumn{6}{|l|}{ Str x PetR x HAppl } \\
\hline Pprop x Ret x Ctrl & $70.0(56.8)$ & $10.0(14.9)$ & $10.0(18.4)$ & 5 & 8.5 \\
\hline Pprop x Ret x S3P & $70.0(57.7)$ & $10.0(11.1)$ & $10.0(15.0)$ & 4 & 11.4 \\
\hline Pprop x Nret x Ctrl & $40.0(38.9)$ & $20.0(26.1)$ & $10.0(18.4)$ & 4 & 9.3 \\
\hline Pprop x Nret x S3P & $53.3(47.0)$ & $20.0(26.1)$ & $10.0(15.0)$ & 4 & 11.1 \\
\hline Pbin $\times$ Ret $\times$ Ctrl & $70.0(58.9)$ & $10.0(18.4)$ & $10.0(11.1)$ & 4 & 12.2 \\
\hline Pbin $x$ Ret $\times$ S3P & $80.0(75.3)$ & $10.0(18.4)$ & $0.0(0.0)$ & 7 & 15.2 \\
\hline Pbin $\times$ Nret $\times$ Ctrl & $40.0(39.1)$ & $30.0(33.0)$ & $40.0(38.9)$ & 4 & 2.9 \\
\hline Pbin $\times$ Nret $\times$ S3P & $60.0(50.9)$ & $0.0(0.0)$ & $50.0(45.0)$ & 3 & 6.1 \\
\hline Ptunnel x Ret x Ctrl & $20.0(26.1)$ & $33.3(34.2)$ & $20.0(26.1)$ & 3 & 6.7 \\
\hline Ptunnel x Ret x S3P & $30.0(33.3)$ & $10.0(18.2)$ & $40.0(38.9)$ & 5 & 8.5 \\
\hline Ptunnel x Nret x Ctrl & $10.0(15.0)$ & $20.0(26.6)$ & $50.0(45.1)$ & 6 & 12.9 \\
\hline Ptunnel x Nret x S3P & $30.0(32.4)$ & $10.0(11.1)$ & $10.0(15.0)$ & 3 & 7.3 \\
\hline $\operatorname{LSD}(P=0.05)$ & (15.6) & (18.5) & (19.0) & ns & 1.9 \\
\hline
\end{tabular}

Figures in parenthesis are angular transformed values

Prop- polythene propagator, Pbin- Propagating bin, Ptunnel- Polythene tunnel, Ret- Retained, Nret- Not retained, S3PSeradix 3 powder, Crtl-Control, HAppl-Hormone application, Struc- Structure, PetR- Petiole retention 
Agric. Biol. J. N. Am., 2011, 2(2): 258-269

Table 4: Levels of sugars and total free phenols in rejuvenated cuttings sampled from the 3 propagating structures with and without petiole

\begin{tabular}{|c|c|c|c|c|c|}
\hline \multirow[t]{2}{*}{ Structure } & \multirow[t]{2}{*}{ Treatment } & \multicolumn{3}{|c|}{ Sugars (mg/g) } & \multirow{2}{*}{$\begin{array}{l}\text { Total free } \\
\text { phenols } \\
(\mathrm{ug} / \mathrm{g})\end{array}$} \\
\hline & & Soluble & Insoluble & Total & \\
\hline \multirow[t]{2}{*}{ Polythene propagator } & + & 32.6 & 99.7 & 132.3 & 157.8 \\
\hline & & 18.5 & 84.9 & 103.4 & 100.5 \\
\hline \multirow[t]{2}{*}{ Propagating bin } & + & 34.4 & 103.5 & 136.9 & 165.4 \\
\hline & & 18.9 & 82.0 & 104.9 & 110.5 \\
\hline \multirow[t]{2}{*}{ Propagating tunnel } & + & 21.9 & 98.5 & 120.4 & 143.8 \\
\hline & 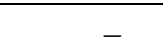 & 16.4 & 77.6 & 94.0 & 97.8 \\
\hline $\operatorname{LSD}(P=0.05)$ & & 10.6 & 12.5 & 12.8 & 26.9 \\
\hline
\end{tabular}

Structure $\mathrm{x}$ irrigation $\mathrm{x}$ hormone interaction was significant $(P<0.05)$ except for the number of cuttings that formed callus. Significantly high numbers of rooted cuttings, roots developed per cutting and long roots were recorded for cuttings that were treated with Seradix powder, irrigated once daily and set in the propagating bin. Cuttings irrigated thrice daily without hormone treatment and set in the polythene propagator did not root (Table 5). The polythene tunnel recorded low rooting. The propagating bin as the best structure in rooting performance for cuttings which were irrigated once daily and treated with Seradix powder hormone could be due to its ability in maintaining a medium temperature thus enhancing auxin biosynthesis (Leopold, 1960) and reducing leaching of essential soluble plant substances responsible for rooting as observed by Hartmann et al. (2002).

Cuttings in the propagating bin significantly recorded the highest level of soluble and insoluble sugars. However, the phenol levels for the treatments in the polythene propagator were significantly different from cuttings in the propagating bin. Hartmann et al. (2002) observed that irrigation causes the leaching of some essential plant substances responsible for rooting (Table 6).
Retention of petiole did not significantly affect normal death and leaf drop of shea stem cuttings (Table 7). However, infection occurred on cuttings that were set in the polythene tunnel. Cuttings with petioles recorded low infection in all the structures than those without. The same results were observed on the leaves. Hartmann et al. (2002) reported that high temperatures and moisture content are optimal for pathogenic influence and this was observed in the polythene tunnel, which recorded high temperatures than the other structures.

The structure, irrigation interaction did not show any significant difference in the normal death of cuttings and leaf drop (Table 8). However, a high degree of infection was observed in the polythene tunnel with increasing frequency of irrigation. Irrigating the cuttings thrice daily in the polythene tunnel resulted in a lot of deaths and leaf drop. The abnormally high temperatures with high humidity figures recorded in the tunnel could have enhanced rapid fungal growth (Hartmann et al., 2002) resulting in the destruction of the cells in the cuttings as observed by Yoder (1980) and Otani et al. (1985). 
Table 5: Effect of types of propagating structure, irrigation and hormone application and their interaction on the rooting of shea stem cuttings.

\begin{tabular}{|c|c|c|c|c|c|}
\hline & $\%$ of cutting & ve after 120 & & & \\
\hline & Rooted & Callused & Dormant & $\begin{array}{l}\text { No. of roots } \\
\text { per cutting }\end{array}$ & $\begin{array}{l}\text { Average root length } \\
(\mathrm{cm})\end{array}$ \\
\hline Treatment & & & & & \\
\hline Structure & & & & & \\
\hline Pprop & $23.9(23.3)$ & $23.3(27.2)$ & $15.0(17.8)$ & 3.11 & 6.0 \\
\hline Pbin & $30.1(27.5)$ & $31.8(31.8)$ & 13.9 (19.1) & 2.39 & 7.5 \\
\hline Ptunnel & $12.5(17.0)$ & $36.7(36.8)$ & $14.4(16.4)$ & 2.33 & 4.1 \\
\hline $\operatorname{LSD}(P=0.05)$ & $(9.2)$ & (7.4) & (ns) & ns & 1.1 \\
\hline Irrig & & & & & \\
\hline Once & $37.2(34.8)$ & $30.8(32.4)$ & $22.8(25.3)$ & 3.06 & 7.6 \\
\hline Twice & $20.8(22.8)$ & $22.5(26.9)$ & $16.7(21.5)$ & 3.33 & 6.6 \\
\hline Thrice & $6.7(10.3)$ & $37.5(36.5)$ & $3.9(6.5)$ & 1.44 & 6.0 \\
\hline $\operatorname{LSD}(P=0.05)$ & $(9.2)$ & $(7.4)$ & (6.3) & 1.6 & Ns \\
\hline Horm Appl & & & & & \\
\hline Ctrl & 8.9 (11.5) & 33.9 (34.9) & $19.6(21.3)$ & 2.33 & 5.7 \\
\hline S3P & $34.3(33.7)$ & $26.7(29.0)$ & $9.3(14.2)$ & 2.89 & 6.8 \\
\hline $\operatorname{LSD}(P=0.05)$ & $(7.3)$ & (ns) & $(5.1)$ & ns & 0.6 \\
\hline Struc / Irrig / Horm App & & & & & \\
\hline Pprop x Once $\times$ Ctrl & $10.0(15.00)$ & 40.0 (39.1) & $30.0(31.9)$ & 3.0 & 9.4 \\
\hline Pprop x Once $\times$ S3P & $73.3(60.0)$ & $20.0(25.4)$ & $10.0(18.4)$ & 5.0 & \\
\hline Pprop x Twice x Ctrl & $10.0(15.0)$ & $10.0(18.4)$ & $40.0(38.1)$ & 5.33 & 4.8 \\
\hline Pprop x Twice $\times$ S3P & $40.0(38.9)$ & $20.0(26.1)$ & $10.0(18.4)$ & 4.33 & 6.8 \\
\hline Pprop $\times$ Thrice $\times$ Ctrl & $0.0(.0 .0)$ & $30.0(32.3)$ & $0.0(0.0)$ & 0.0 & 0.0 \\
\hline Pprop x Thrice $\times$ S3P & $1.0(11.1)$ & $20.0(21.9)$ & $0.0(0.0)$ & 1.0 & 3.2 \\
\hline Pbin $\times$ Once $\times$ Ctrl & $20.0(21.1)$ & $35.0(36.0)$ & $30.0(32.3)$ & 1.33 & 2.9 \\
\hline Pbin $x$ Once $\times$ S3P & $80.0(64.6)$ & $20.0(21.9)$ & $0.0(0.0)$ & 8.33 & 15.6 \\
\hline Pbin $\times$ Twice $\times$ Ctrl & $10.0(11.1)$ & $40.0(39.2)$ & $10.0(17.5)$ & 2.0 & 10.4 \\
\hline Pbin $\times$ Twice $\times$ S3P & $40.0(38.1)$ & $15.0(18.9)$ & $20.0(26.1)$ & 6.33 & 5.7 \\
\hline Pbin $\times$ Thrice $\times$ Ctrl & $5.0(7.6)$ & $35.0(35.6)$ & $10.0(18.4)$ & 2.0 & 8.4 \\
\hline Pbin $\times$ Thrice $\times$ S3P & $15.0(22.6)$ & $40.0(39.2)$ & $13.3(20.5)$ & 1.3 & 2.0 \\
\hline Ptunnel x Once x Ctrl & $10.0(15.0)$ & $30.0(32.7)$ & $46.7(42.8)$ & 2.33 & 4.1 \\
\hline Ptunnel $\times$ Once $\times$ S3P & $30.0(33.0)$ & $40.0(32.7)$ & $20.0(26.6)$ & 1.33 & 1.8 \\
\hline Ptunnel $\times$ Twice $\times$ Ctrl & $10.0(15.0)$ & $30.0(33.0)$ & $10.0(11.1)$ & 3.0 & 5.7 \\
\hline Ptunnel x Twice XS3P & $15.0(22.6)$ & $20.0(26.1)$ & $10.0(18.0)$ & 3.0 & 6.1 \\
\hline Ptunnel x Thrice $\times$ Ctrl & $5.0(7.6)$ & $55.0(48.0)$ & $0.0(0.0)$ & 2.0 & 5.8 \\
\hline Ptunnel x Thrice xS3P. & $5.0(12.9)$ & $45.0(42.2)$ & $0.0(0.0)$ & 2.33 & 8.2 \\
\hline Interaction $\operatorname{LSD}(P=0.05)$ & (22.7) & (ns) & $(15.3)$ & 3.3 & 8.0 \\
\hline
\end{tabular}

ns- not significant Figures in parenthesis are angular transformed values

Pprop- Polythene propagator, Pbin- Propagating bin, Ptunnel- Polythene tunnel,Ctrl-Control, S3P- Seradix powder, Horm Appl.-Hormome application, Irrig- Irrigation, Struc-Structure 
Agric. Biol. J. N. Am., 2011, 2(2): 258-269

Table 6: Levels of sugars and total free phenols in rejuvenated cuttings sampled from the 3 propagating structures irrigated at different frequencies

\begin{tabular}{|l|l|l|l|l|l|}
\hline \multirow{2}{*}{ Structure } & \multirow{2}{*}{ Treatment } & \multicolumn{2}{|c|}{ Sugars $(\mathrm{mg} / \mathrm{g})$} & $\begin{array}{l}\text { Total } \\
\text { phenols }\end{array}$ \\
\cline { 3 - 6 } & & Soluble & Insoluble & Total & \\
\hline \multirow{3}{*}{ Polythene propagator } & Once & 34.5 & 89.4 & 123.9 & 151.8 \\
\cline { 2 - 6 } & Twice & 29.5 & 56.5 & 86.0 & 139.0 \\
\cline { 2 - 6 } & Thrice & 24.9 & 21.8 & 46.7 & 104.7 \\
\hline \multirow{3}{*}{ Propagating bin } & Once & 35.1 & 92.3 & 127.4 & 147.7 \\
\cline { 2 - 6 } & Twice & 27.9 & 81.8 & 109.7 & 129.2 \\
\cline { 2 - 6 } & Thrice & 24.8 & 68.4 & 93.2 & 115.5 \\
\hline \multirow{3}{*}{ Polythene tunnel } & Once & 20.4 & 77.0 & 97.4 & 141.9 \\
\cline { 2 - 6 } & Twice & 17.5 & 62.8 & 80.3 & 128.1 \\
\cline { 2 - 6 } & Thrice & 15.8 & 59.6 & 75.4 & 115.5 \\
\hline \multirow{2}{*}{ LSD $(P=0.05)$} & & 12.3 & 10.9 & 12.3 & 28.6 \\
\hline
\end{tabular}

Table 7: Degree of infection on cuttings set in types of propagating structure and petiole (leaf stalk) retention

\begin{tabular}{|l|c|c|c|c|c|}
\hline \multirow{2}{*}{ Structure } & \multirow{2}{*}{$\begin{array}{c}\text { Nature of } \\
\text { petiole on } \\
\text { cuttings }\end{array}$} & \multicolumn{2}{|c|}{$\begin{array}{c}\text { \% of cuttings dead } \\
\text { after } 120 \text { days }\end{array}$} & \multicolumn{2}{c|}{$\begin{array}{c}\text { \% of leaves dropped on cuttings } \\
\text { after 120 days }\end{array}$} \\
\cline { 3 - 6 } & & Normal & Infected & Normal & Infected \\
\hline Polythene propagator & + & $10.0(15.0)$ & $5.0(10.5)$ & $20.0(22.3)$ & $10.0(18.0)$ \\
\hline Polythene propagator & - & $10.0(11.1)$ & $10.0(18.4)$ & $20.0(17.5)$ & $10.0(14.3)$ \\
\hline Propagating bin & + & $10.0(17.5)$ & $0.0(0.0)$ & $24.0(21.2)$ & $10.0(15.2)$ \\
\hline Propagating bin & - & $10.0(18.4)$ & $4.3(9.5)$ & $22.3(21.1)$ & $20.0(26.6)$ \\
\hline Polythene tunnel & + & $20.0(16.1)$ & $43.3(41.1)$ & $30.0(33.0)$ & $33.3(35.0)$ \\
\hline Polythene tunnel & - & $20.0(21.0)$ & $50.0(45.0)$ & $31.0(31.9)$ & $60.0(51.1)$ \\
\hline LSD $(P=0.05)$ & & $(\mathrm{ns})$ & $(11.0)$ & $(\mathrm{ns})$ & $(18.1)$ \\
\hline
\end{tabular}

$(+)$ with petiole (-) without petiole Figures in parenthesis are angular transformed ns- not significant

Table 8: Degree of infection on cuttings set in the types of propagating structure and irrigation frequency.

\begin{tabular}{|c|c|c|c|c|c|}
\hline \multirow[t]{2}{*}{ STRUCTURE } & \multirow{2}{*}{$\begin{array}{l}\text { Frequency } \\
\text { of } \\
\text { Irrigation }\end{array}$} & \multicolumn{2}{|c|}{$\begin{array}{l}\% \text { of cuttings dead } \\
\text { after } 120 \text { days }\end{array}$} & \multicolumn{2}{|c|}{$\begin{array}{l}\% \text { of leaves dropped on cuttings } \\
\text { after } 120 \text { days }\end{array}$} \\
\hline & & Normal & Infected & Normal & Infected \\
\hline \multirow[t]{3}{*}{ Polythene propagator } & Once & $10.0(11.0)$ & $6.0(14.1)$ & 10.5 (16.9) & $4.1(11.6)$ \\
\hline & Twice & $10.0(13.1)$ & $15.0(22.8)$ & $14.5(12.6)$ & $23.0(28.6)$ \\
\hline & Thrice & $10.6(15.3)$ & $20.0(26.5)$ & $14.3(13.3)$ & $31.4(31.0)$ \\
\hline \multirow[t]{3}{*}{ Propagating bin } & Once & $12.0(10.0)$ & $5.0(12.8)$ & $15.3(13.5)$ & $5.2(13.2)$ \\
\hline & Twice & $13.0(12.2)$ & $10.0(18.3)$ & $15.0(12.9)$ & $20.3(26.5)$ \\
\hline & Thrice & 15.0 (12.1) & $15.0(22.7)$ & $20.1(22.4)$ & $30.4(42.0)$ \\
\hline \multirow[t]{3}{*}{ Polythene tunnel } & Once & $15.0(12.9)$ & $20.0(26.5)$ & $12.9(20.7)$ & $20.0(26.1)$ \\
\hline & Twice & $16.0(14.2)$ & $30.0(32.3)$ & $20.3(22.2)$ & $50.4(45.3)$ \\
\hline & Thrice & $20.0(17.1)$ & $60.0(57.0)$ & $23.2(21.8)$ & $64.5(56.2)$ \\
\hline $\operatorname{LSD}(P=0.05)$ & & (ns) & (10.1) & (ns) & $(7.5)$ \\
\hline
\end{tabular}

ns- not significant

Figures in parenthesis are angular transformed values. 


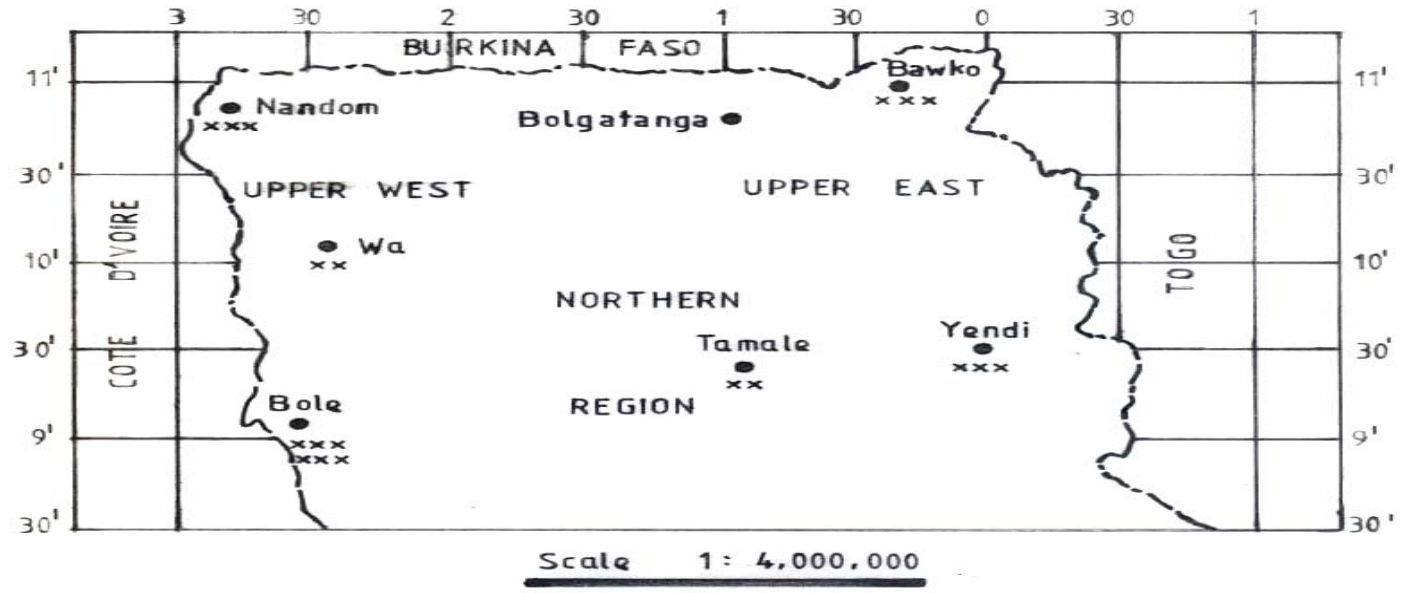

Fig. 1 Map of Northern Ghana

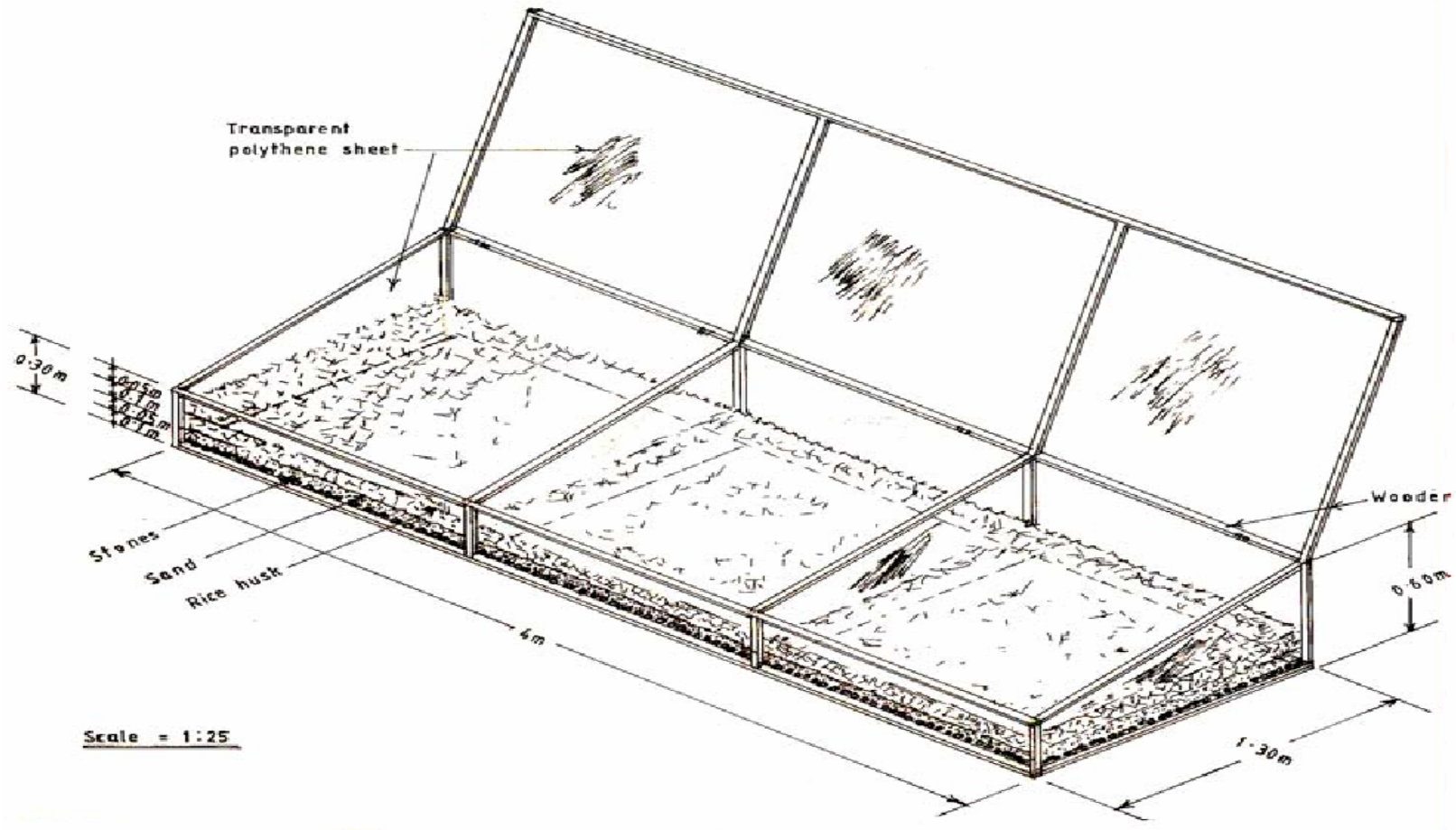

Fig. 2 The polythene propagator used in the experiments showing arrangements of stones, gravels and growing medium. 
Agric. Biol. J. N. Am., 2011, 2(2): 258-269

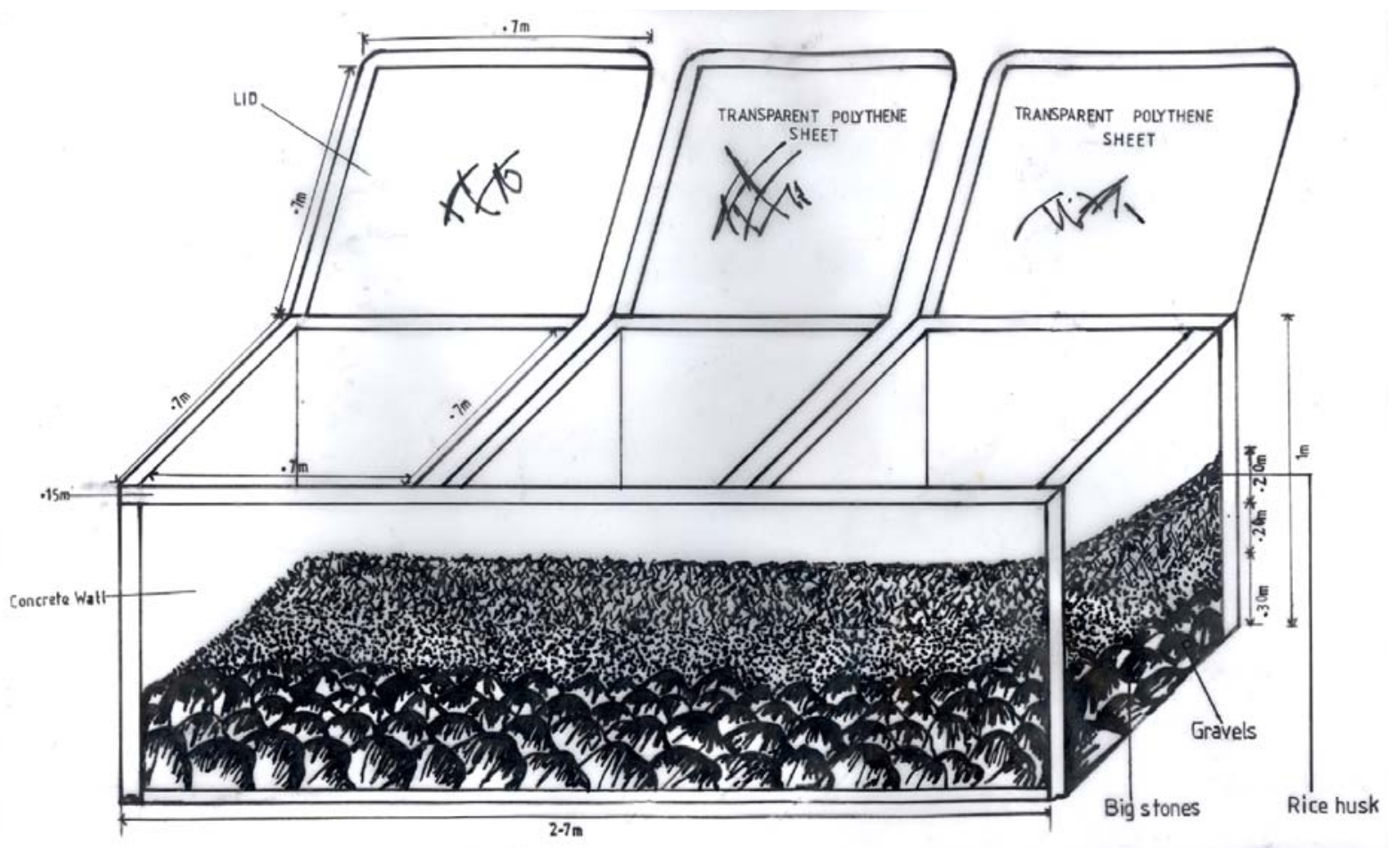

Fig. 3 Propagating bin covered with transparent polythene sheet

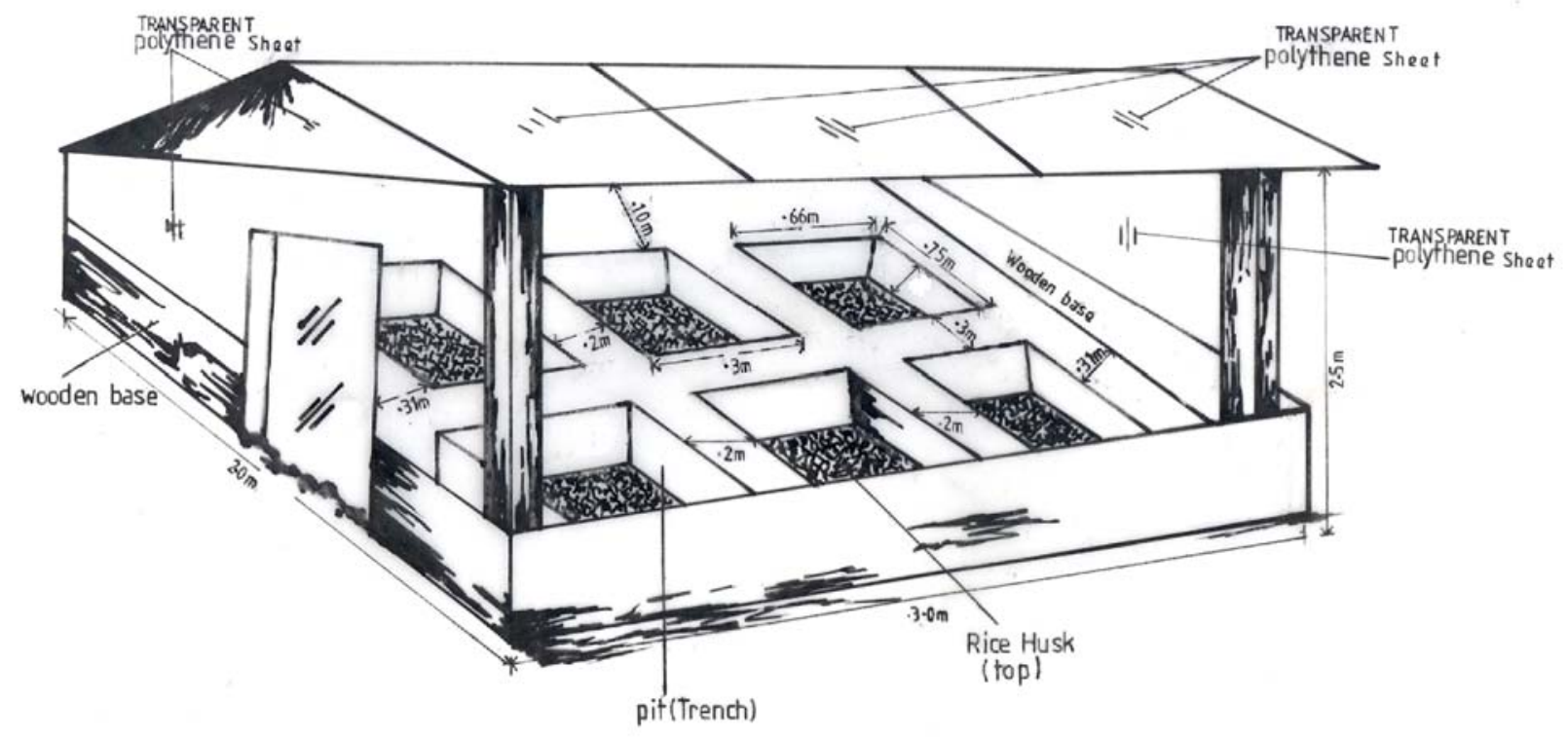

Fig 4 Propagating tunnel covered with white polythene sheet showing the arrangements of stones, gravels and growing medium. 


\section{CONCLUSION}

The propagating bin among the structures studied enhanced rooting in the shea stem cuttings. Cuttings set with retained petioles were the best for rooting. Irrigating once on cuttings in the structures, especially in the propagating bin recorded high rooting. Plant substances like sugars and total free phenols played a very significant role in rooting of stem cuttings. The degree of infection was low when cuttings with retained petioles were irrigated once daily. The Seradix hormone enhanced the rooting performance of the shea stem cuttings. When the petioles were retained on the cuttings, levels of soluble and insoluble sugars and phenols were high. This was also observed for irrigating once, which gave higher levels.

\section{ACKNOWLEDGEMENTS}

We wish to express our thanks to the technical staff at the CRIG substation, Bole and Physiology/ Biochemistry Division for the data collection and chemical analysis respectively. This paper (No. CRIG/122009/017/001) is published with the kind permission of the Executive Director, CRIG.

\section{REFERENCES}

Balestrini, S. and Vartanian N. (1983). Rhizogenic activity during water stress-induced senescence in Brassica napus var oleifera. Physiologie Vegetale, 21: 269-277.

Bayala, J., Teklehaimanot, Z. and Ouadraogo, S. J. (2002). Millet production under pruned tree crowns in a parkland system in Burkina Faso. Agroforestry Systems 54:203-214

Davis, T.D. and Hassig, B.E. (1990). Chemical control of adventitious root formation in cuttings. Bull. Plant Growth Reg. Soc. Amer. 18: 1-17

Dubois, M., Gillies, K.A., Hamilton, J.K., Rebers, P.A. and Smith. F (1956). Colorimetric method for determination of sugars and related substances. Analytical chemistry 28:350 - 455

Erstad, J.L.F. and Gislerod, H.R. (1994). Water uptake and stem pieces as affected by different anaerobic conditions in the rooting medium. Scientia Hort 58: 151160.

Gorter, C.J. (1969). Auxin-synergist in the rooting of cuttings. Plant Physiol. 22:497-502.

Haby, S., Sie, K., Zewge, T., Mamadou, D., Harouna, Y., Sibidou, S., Lompo, D. and Jean-Marc, D. (2004). Vegetative propagation of Vitellaria paradoxa by grafting. Agroforestry Systems. Springer Netherlands. 60(1) 93-99.
Hartmann, H.T., Kester, D.E., Davies, F.T. and Geneve, R.L. (2002). Plant propagation principles and practices. Prentice Hall ENG. Cliff, New Jersey 07632.

Hall, J. B., Aebischer, D. P., Tomlinson, H. F., OseiAmaning, E. and Hindle, J. R. (1996). Vitellaria paradoxa. A Monograph. School of Agricultural and Forest Sciences. University of Wales, Bangor, UK. 105 pp.

Henselova, M., Lux, A. and Masarovicava, E. (2002). Effect of growth regulators on rooting cuttings of Karwinskia species under in vivo conditions. Rostlinna Vyroba, 48 (10) $471-476$.

Leopold, A.C. (1960). Auxins and Plant Growth. $2^{\text {nd }}$ Ed. University of California Press. Berkeley and Los Angeles.

Lux, A., Liscova, D., Masarovicova, E., Kakoniova, D., Hanackova, Z., Argalasova-Sutovska, K., Kollarova, K., Henselova, M., Ruiz Ordonez, J. and Pineyro Lopez, A. (2002). Biology of Karwinskia spp., experimental cultivation and secondary metabolite production. In:Govil JN, Ananda Kumar P, Singh PK (eds). Recent progress in medicinal plants. Vol.4. Biotechnology and Genetic Engineering. Sci. Techn. Publ. Houston: $175-$ 200.

Mackelvie, A.D. (1957). The polythene sheet method of rooting cacao cuttings. Trop Agric 34: 260-265.

Maranz, S. K., Walter, Z., Wiesman, A., De Saint Sauveur and Chapagain, B. (2004). Nutritional values and indigenous preferences for shea fruits (Vitelleria paradoxa C.F. Gaertn.) in African Agroforestry Parklands. Econ. Bot., 58: 588-600.

Middleton, W., Jarvis, B.C. and Booth, A. (1978. The boron (B) requirement for root development in stem cuttings of Phaseolus aureus Roxb. The New Phytologist. 81(2): 287-297.

Middleton, W., Jarvis, B.C. and Booth, A. (1980.) The Role of leaves in auxin and boron-dependent rooting of stem cuttings of Phaseolus aureus Roxb. The New Phytologist 84(2): 251-259.

Moore, K.G., Illsley, A. and Lovell, P.H. (1975). The effects of temperature on root initiation in detached cotyledons of Sinapis alba L. Annals of Botany 39: 657-669.

Murray, D. B. and Bridge, C. J. R. (1956). A comparison of various methods of rooting cacao cuttings. A report on cacao research. 1955-56. Imperial College of Tropical Agriculture, Trinidad. Pp 41- 44.

Nanda, K.K., Purohit, A.N. and Anand, V.K. (1968). Seasonal rooting response of stem cuttings of some forest tree species to auxins. Indian Forest 154-162. 
Nawrocka-Grzeskowiak, U. and Grzeskowiak, W. (2003). Rooting of Azalea shoot cuttings depending on the degree of lignification. Dendrobiology 49: 53-56

Nicholas, R. (1958). Propagation of cacao in plastic bags. Nature 180:181.

Ofori-Gyamfi, E. (1998) Investigation into some factors affecting vegetative propagation of coffee (Coffea canephora var Robusta Pierre). M. Phil thesis. University of Cape Coast, Cape Coast, Ghana p173.

Opoku-Ameyaw, K. (1996). Shea experiments. Report, Cocoa Research Institute of Ghana, Bole Substation. 1995/1996. p225-228.

Opoku- Ameyaw, K., Amoah, F.M. and Yeboah, J. (2000) Studies into vegetative propagation on the sheanut tree (Vitellaria paradoxa Gaertn). Jour. of Ghana Sci. Assoc 4(2) 138-145.

Otani, H., Haramoto, M., Kohmoto, K. and Nishimura, S. (1985). Two different phases in host cell damages induced by AK-toxin of Alternaria alternata Japanese pear pathotype. J. faculty of Agric. of Yottori Univ. 20:8-17.
Pearson, D. (1976). The chemical analysis of Foods. $7^{\text {th }}$ Edn., Church-Hill Livingstone London, pp: 488497.

Preece, J.E. (1993). Basics of propagation by cuttingstemperature. Comb. Proc. Intl. Plant Prop. Soc. 43: 441- 443.

Rein, R.H., Wright, R.D. and Seiler, J.R. (1991). Propagation medium moisture level influences adventitious rooting of woody stem cuttings. J. Amer. Soc. Hort. Sci. 116: 632 - 636.

Swain, T. and Hillis, W.E. (1959). The phenolic constituents of Prunus domestica. I. The quantitative analysis of phenolic constituents. J. Sci. Food Agric 10(1): 63-68.

Yeboah, J. (2005). Studies into the vegetative propagation of the sheanut tree (Vitellaria paradoxa Gaertn) using stem cuttings. M. Phil. Thesis, Kwame Nkrumah University of Science and Technology, Kumasi, Ghana. pp. 80-82.

Yoder, O.C. (1980). Toxins in pathogenesis. Annual Review of phytopathology 103-129.

Zahner, F. (1968). Water deficit and growth of trees. In Kozlowski TT (ed.) "Water Deficit and Plant Growth". Vol.2. Academic Press, New York, pp 191-254. 